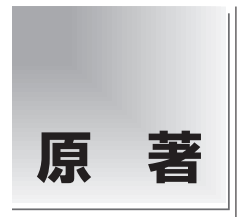

論文受付

2018 年 11 月 2 日

論文受理

2019 年 5 月 22 日

Code No. 430

\section{ゴールデンビームデータを用いた}

効率的な治療計画装置コミッショニング

広木智之 ${ }^{1}$ 藤田幸男 $^{2}$ 前平祥太 $^{1}$ 早田憲治 $^{1}$ 菊地朋子 $^{1}$ 國枝悦夫 $^{3}$

\author{
${ }^{1}$ 東海大学医学部付属病院放射線技術科 \\ 2 東海大学医学部放射線治療科学 (現 駒澤大学診療放射線技術科学科) \\ 3 東海大学医学部放射線治療科学
}

\section{緒 言}

リニアックの臨床導入に際しては, 幾何学的精度等 のリニアック本体の精度評価だけではなく, 治療計画 装置に登録するための多数のビームデー夕測定が必須 であり，一般的にベンダからの装置受け渡し後 3〜4 カ月の期間を要する ${ }^{1)}$ 。この臨床導入のための準備作 業であるコミッショニングの工程では22，煩雑なビー
ムデー夕測定のみならず，デー夕の加工や検証，登録 作業にも多くの時間を要することが問題となる。また 治療計画装置へのデー夕入力誤り等, 治療計画装置の コミッショニングに由来するインシデントが世界的に 多く報告されており ${ }^{3)}$, 安全管理の面からも作業の単 純化・簡略化，およびチェック体制の構築は重要な課 題である。しかしながら臨床ニーズや経済的な面か

\title{
Efficient Commissioning of the Radiotherapy Treatment Planning System with the Golden Beam Data
}

Tomoyuki Hiroki, ${ }^{1 *}$ Yukio Fujita, ${ }^{2}$ Shota Maehira, ${ }^{1}$ Kenji Soda, ${ }^{1}$ Tomoko Kikuchi, ${ }^{1}$ and Etsuo Kunieda ${ }^{3}$

${ }^{1}$ Department of Radiology, Tokai University Hospital

${ }^{2}$ Department of Radiation Oncology, Tokai University School of Medicine (Current address: Department of Radiological Sciences, Komazawa University)

${ }^{3}$ Department of Radiation Oncology, Tokai University School of Medicine

Received November 2, 2018; Revision accepted May 22, 2019

Code No. 430

\section{Summary}

Commissioning of a linear accelerator (Linac) and treatment planning systems (RTPs) for clinical use is complex and time-consuming, typically 3-4 months in total. However, based on clinical needs and economics, hospitals desire early clinical starts for patients, and various studies have been conducted for shortening the preparation period. One of the methods to shorten the period is using golden beam data (GBD). The purpose of this study was to shorten the commissioning period without reducing accuracy and to simplify commissioning works while improving safety. We conducted commissioning of the RTPs before installing the Linac using GBD, and carried out verification immediately after the acceptance test. We used TrueBeam STx (Varian Medical Systems) and Eclipse (ver. 13.7, Varian Medical Systems) for RTPs and anisotropic analysis algorithm (AAA) and AcurosXB (AXB) for calculation algorithms. The difference between GBD and the measured beam data was $0.0 \pm 0.2 \%$ [percentage depth dose (PDDs) ] and $-0.1 \pm 0.2 \%$ (Profiles) with X-ray, and $-1.2 \pm 1.3 \%$ (PDDs) with electrons. The difference between the calculated dose and the measured dose was $0.1 \pm 0.3 \%$ (AAA) and $0.0 \pm 0.3 \%$ (AXB) under homogeneous conditions, and $0.7 \pm 1.4 \%$ (AAA) and $0.6 \pm 1.1 \%$ (AXB) under heterogeneous conditions. We took 43 days from the end of the acceptance test to the start of clinical use. We found that the preparation period for clinical use can be shortened without reducing the accuracy, by thinning out the number of measurement items using GBD.

Key words: radiotherapy treatment planning system, commissioning, golden beam data, representative beam data, dose calculation algorithm

*Corresponding author 
ら，早期の使用開始が望まれており，期間短縮に向け た種々の検討がなされている.

準備期間を短縮する方法の一つにゴールデンビーム デー夕 (golden beam data: GBD ${ }^{4)}$ を用いる方法があ る. GBD とは, ベンダが提供する特定のリニアック 機種における代表データであり，主に施設で測定され たビームデータ (measured beam data: MBD)の比較検 証等に用いられる ${ }^{4)}$. 治療計画装置のコミッショニン グにおいて，GBD をビームデータとして登録するこ とで, 測定作業およびデー夕加工作業等を簡略化し, 期間短縮を図る方法について検討がなされている5 ${ }^{5}$. GBD に関する先行研究では, 近年の治療装置は精度 が高く, 個体間のビーム特性のばらつきが小さいこと が報告されている TrueBeam に扔ける GBD と MBD の比較結果を示し ており，概ね 1\%以内で一致したと報告している9 .

しかし，これらの報告では GBD の有用性については 言及しているが，GBDの具体的な利用法については 検討されていない. また具体的にどの程度準備期間を 短縮できたかを示す報告もない。

本研究では当院のリニアック新規導入に際し, ベン ダが提供する GBD を用いて, リニアック据付前に治 療計画装置のビームモデリングとコミッショニング用 データの準備を行い, 受入試験終了後即座に抜き取り 検証を行うことで, 精度を落とすことなくコミッショ ニング期間の短縮を図った。また手作業によるデー夕 入力を最小限にし、コミッショニング作業を単純化す ることで, 安全性の向上を図った。今回, われわれは GBD と MBD の単純比較だけでなく, GBD 単独での 線量計算アルゴリズムのモデリング結果や, 実際に要 した準備期間について, 詳細に検証を行ったので報告 する。

\section{1. 方 法}

\section{1-1 コミッショニング計画の概要}

Figure 1 に本研究で実施したコミッショニングの 概要を示す，通常はリニアック据付後に実施される治 療計画装置のビームモデリングとコミッショニング用 データの準備を事前に行うことで, 臨床使用開始まで の期間短縮を図った。各項目の詳細は後述する.

\section{1-2 使用機器}

リニアックは TrueBeam STx (Varian Medical Systems 社), 治療計画装置は Eclipse ver.13.7 (Varian Medical Systems 社) を用いた。使用エネルギーはX 線の平坦ビーム (flattening filtered beam: FF) が 4,6 ,

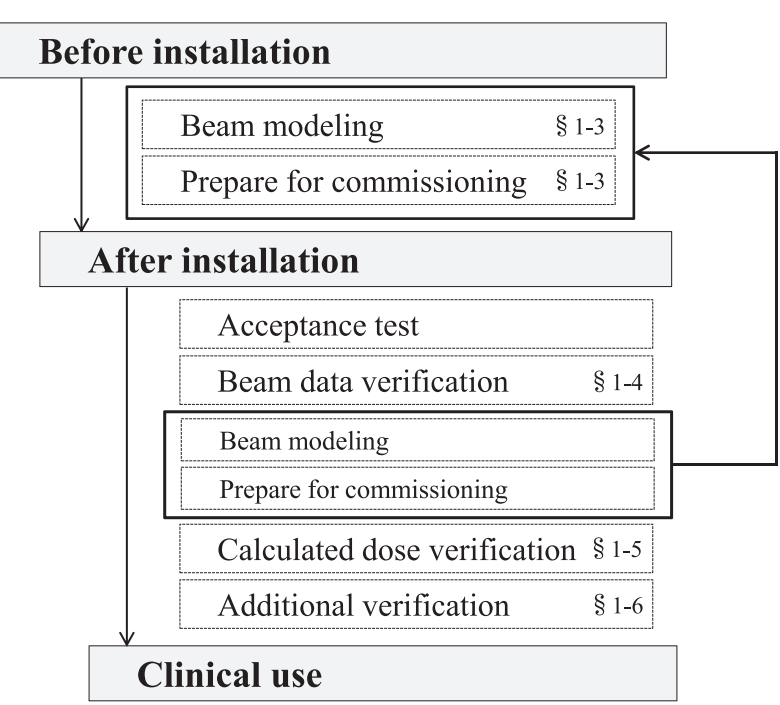

Fig. 1 An outline of commissioning carried out in this study.

$8,10 \mathrm{MV}$, 非平坦ビーム (flattening filter free beam: $\mathrm{FFF})$ が $6,10 \mathrm{MV}$ ，電子線が $6 ， 9 ， 12 ， 15 ， 18 ， 20$ $\mathrm{MeV}$ である。ビームデータ測定には Blue Phantom 2 (IBA Dosimetry 社)を使用し, 電離箱線量計は CC13 (IBA Dosimetry 社)を用いた。これら電離箱の選定 を含め, 電離箱の走査方法や取得ビームデータの後処 理方法については, GBD の測定条件に準じた ${ }^{10)}$ 。ま た, GBD でモデリングした Eclipse の計算線量を, 均 質媒質掞よび不均質媒質条件にて電離箱線量計を用い て検証を行った。使用ファントム，電離箱線量計はそ れぞれ均質媒質が Blue Phantom 2, Exradin A12 Ion Chamber (Standard Imaging 社), 不均質媒質条件が Model 002LFC (CIRS 社), CC13であり, 詳細な検証 方法については 1-5 で述べる。線量計算アルゴリズム は Anisotropic analytical algorithm(AAA) ver.13.7 お よびAcurosXB (AXB) ver.13.7を用い, 線量計算グ リッドは臨床使用条件に合わせ，それぞれ $2.5,2.0$ $\mathrm{mm}$ とした。

\section{1-3 治療計画装置の事前コミッショニング}

TrueBeam および TrueBeam STx だは, GBD に相 当するビームデータとして, Duke Universityの 3 台 の TrueBeam の平均ビームデータが TrueBeam representative beam data (TRBD) として公開されてい $ろ^{6.10)}$. TRBD には, 深部線量百分率 (percentage depth dose: PDD), オープン照射野プロファイル, 出 力係数 (output factor: OPF) 等のデータが含まれてお り,これらはすべて $\mathrm{w} 2 \mathrm{CAD}$ 形式のファイルで公開さ れているため, Eclipseにそのままファイルを読み込 むだけでビームモデリングを行うことができる。ま 
た, Microsoft Excel 形式のファイルも用意されてお

り，より簡便に詳細な検証が可能となっている.

本研究では, w2CAD 形式のファイルを用いてリニ アック搬入前に Eclipse 内の光子線線量計算アルゴリ ズムのモデリングを行い，検証に用いる治療計画につ いても事前に作成した，検証用治療計画の詳細につい ては後述する。

\section{1-4 ビームデータの検証}

ベンダが推奨するビームモデリング項目のうち, 指 定された照射野サイズおよび測定深からX線は約 30\%, 電子線は約 70\%の項目を抜き取り, 三次元水 ファントムを使用し測定を行った．測定ジオメトリは TRBD の測定条件 ${ }^{10)}$ に準じて線源表面間距離(source surface distance: SSD) $100 \mathrm{~cm}$ とし, PDD, プロ ファイルともに電離箱の実効中心にて測定を行った。 取得したデー夕に対して，メディアンフィルタを用い た平滑化処理を施したのち, PDD は最大線量点にて, プロファイルは central axis (CAX) にて線量の正規化 を行った。これら処理後のデータを $\mathrm{MBD}$ とし, TRBD と比較検証を行った。比較の際, MBD は TRBD の sampling 間隔 $(1 \mathrm{~mm})$ に合わせ, Microsoft Excel 上で resampleを実施した，2点間の補間には 直線補間法を用い, resample 後に PDD は最大線量点 で, プロファイルは CAX で再度正規化を行い, 同一 ポイントでの線量差 (dose difference: DD) および同一 線量の位置差 (distance to agreement: DTA)の絶対值 を算出した，PDD において，DDはすべての深さで, また DTA は最大深より深い位置で算出した。プロ ファイルにおいて，DD は設定照射野の $80 \%$ 領域内 で,また DTA は半影部(CAX 線量の 80-20\%の位置) にて算出した，OPF については，TRBDの OPF は基 準深が $5 \mathrm{~cm}$ のデータであり, 標準計測法 12 に記載さ れている定義と異なる ${ }^{11}$. 本研究において，われわれ は効率化を目的としていたため, ビームデー夕の検証 ではスキャンデータのみを検証し, OPF の検証は均 質媒質(水ファントム)を用いた計算線量検証時に合わ せて検証を実施した。具体的な手順は 1-5で述べる。 Table 1 に測定項目数を, Table 2 に主な測定条件を 示す.

\section{1-5 治療計画装置のビームモデルの検証}

$\mathrm{X}$ 線のみ TRBD でモデリングした Eclipse の計算 線量を, 均質媒質㧍よび不均質媒質条件にて電離箱線 量計を用いて検証を行った。均質媒質の検証には BluePhantom 2 およびExradin A12 を用い, SSD=100 $\mathrm{cm}$ における 4-30 cm の正方形照射野および 14 種の ダイナミックウェッジ照射を行い，ビーム中心軸上の 複数の測定深に扔ける水吸収線量を測定し, 同一条件 で計算されたEclipse の線量と比較した。また，同一 測定条件にて，OPFの検証を実施した，基準深 $5 \mathrm{~cm}$ で測定された TRBD の OPF デー夕をそのまま治療計 画装置へ入力し，ビームモデリングを実施した。 $\mathrm{SSD}=100 \mathrm{~cm}$, depth $=10 \mathrm{~cm}, 4-30 \mathrm{~cm}$ の正方形照射野 に打ける計算線量を算出し, 同一ジオメトリの水中線 量と比較することで，間接的に OPF の妥当性を検証 した。不均質媒質の検証には, 胸部不均質ファントム およびCC13 を用い，斜入ビームや不整形照射野，， ンコプラナ照射を含む八つの治療計画 (AXB では ウェッジの設定がないため六つ)を用いて，電離箱に よる実測線量と Eclipseの計算線量を比較した，検証 条件および検証方法について, 均質媒質条件では IAEA Technical Report Series No.43012) を, 不均質媒 質条件では IAEA TECDOC 1583 $3^{13)}$ を参照した。 Table 3 に検証用治療計画の概要を示す.

\section{1-6 その他の準備作業}

ビームデータの検証掞よび計算線量の検証が終わっ たのち, 三次元原体照射, ダイナミックウェッジ照射, 強度変調回転放射線治療 (volumetric modulated arc therapy: VMAT)のコミッショニングを実施した。コ ミッショニングの項目等については各臨床技術におけ る国内外のガイドラインを参考に実施した ${ }^{4,14 \sim 16)}$ 。 た，上記治療技術の検証に加え，リニアックの幾何学 的精度や画像誘導放射線治療等の基礎デー夕の取得, スタッフの教育等を実施した。

\section{1-7 受入試験終了から臨床開始までの期間の検証}

受入試験終了後からビームデー夕検証㧍よび計算線 量検証が終了するまでの期間について，また受入試験 終了から臨床使用開始までの期間について，それぞれ 評価を行った。 なお，上記期間中の休診日についても 一日として数え, 総期間として評価した。

\section{2. 結 果}

\section{2-1 ビームデータの比較}

X 線の TRBD と MBD の DD およびDTA を Fig. 2 に示す。上段にDD を，下段にDTA を示しており， また左にPDDを, 右にプロファイルの結果を示し, 各照射野に㧍ける線量差(または位置差の平均值の絶 対值)を箱ひげ図で示している，TRBD と MBDの $\mathrm{DD}$ は PDD，プロファイルそれぞれ $0.0 \pm 0.2 \%,-0.1 \pm$ 
Table 1 Comparison between number of measurements recommended by the vendor and pre-sampled in our method

\begin{tabular}{|c|c|c|c|c|}
\hline & & Recommended $^{\mathrm{a}}$ & Pre-sampled $^{b}$ & Sampling $\operatorname{ratio}^{\mathrm{c}}(\%)$ \\
\hline \multirow[t]{6}{*}{ Photons } & PDDs & 8 & 4 & 50 \\
\hline & Profiles & 40 & 12 & 30 \\
\hline & Diagonal profiles & 5 & 0 & 0 \\
\hline & OPFs & 144 & 42 & 29 \\
\hline & MLC parameters & 2 & 2 & 100 \\
\hline & Subtotal & 199 & 60 & 30 \\
\hline \multirow[t]{6}{*}{ Electrons } & PDDs with applicator & 5 & 3 & 60 \\
\hline & PDDs w/o applicator & 1 & 0 & 0 \\
\hline & Profiles in air & 1 & 0 & 0 \\
\hline & Absolute dose & 5 & 5 & 100 \\
\hline & Subtotal & 12 & 8 & 67 \\
\hline & Total & 211 & 68 & 32 \\
\hline
\end{tabular}

${ }^{a}$ Measurement items recommended by the vendor

${ }^{\mathrm{b}}$ Sampling items measured in this study

${ }^{\mathrm{C}}$ Sampling ratio $=($ Pre-sampled items $) /($ Recommended items $) * 100$

Table 2 Field sizes and scanning depths for PDDs and OARs recommended by the vendor and pre-sampled in our method

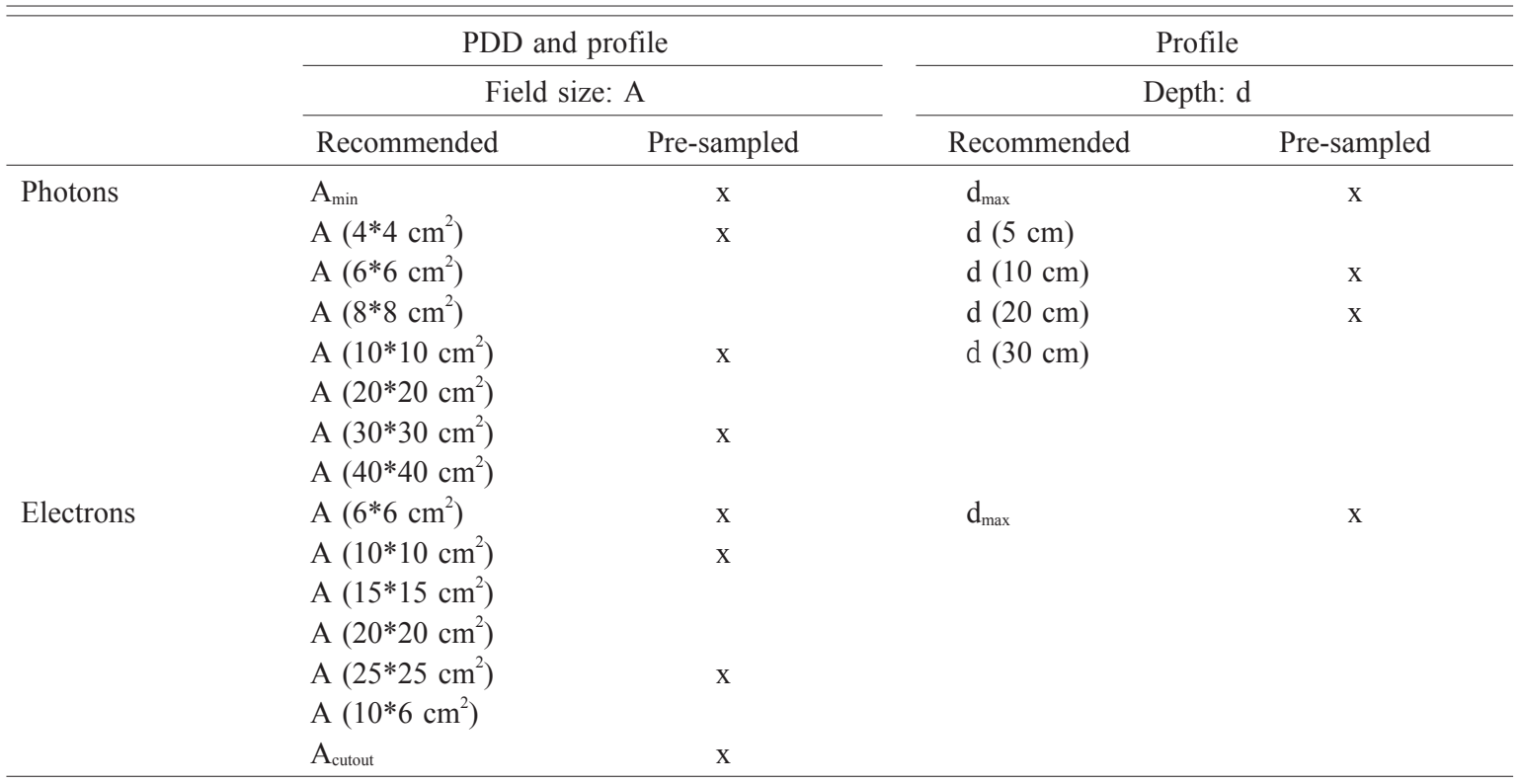

Table 3 Plan description for commissioning of photon dose calculation model

\begin{tabular}{cll}
\hline \hline \multicolumn{1}{c}{ Plan type } & \multicolumn{1}{c}{ Plan name } & \multicolumn{1}{c}{ Description } \\
\hline Simple geometry (Homogeneous) & Photon test 1 & Square and rectangular fields \\
& Photon test 9 & Dynamic (virtual) wedge \\
Clinical (Heterogeneous) & Case 1 & Testing for reference conditions based on CT data \\
& Case 2 & Oblique incidence, lack of scattering and tangential fields \\
& Case 3 & Significant blocking of the field corners \\
& Case 4 & Four field box \\
& Case 5 & Automatic expansion and customized blocking \\
& Case 6 & Oblique incidence with irregular field and blocking the centre of the field \\
& Case 7 & Three fields, two wedge-paired, asymmetric collimation \\
& Case 8 & Non coplanar beams with couch and collimator rotation \\
\hline
\end{tabular}



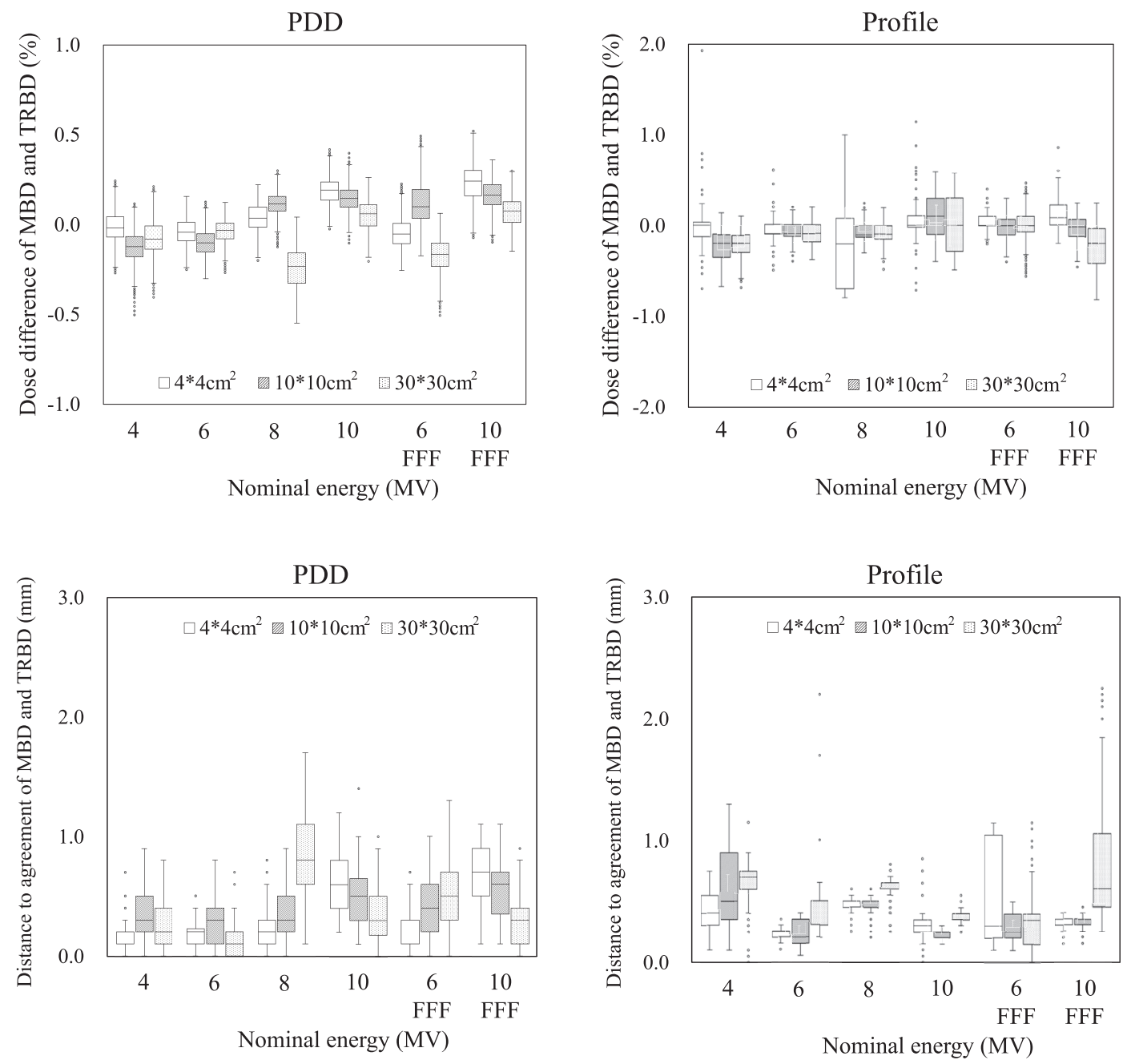

Fig. 2 Box plots of dose difference (upper panels) and distance-to-agreement (lower panels) between TRBD and MBD for PDDs (left panels) and profiles (right panels) for various photon beam energies with field sizes of $4 * 4,10 * 10$, and $30 * 30 \mathrm{~cm}^{2}$. The central mark on the box is the median, while the bottom and top edges indicate the 25th and 75th percentiles, respectively.

$0.2 \%$ であ,またDTAはPDD, プロファイルそれぞ れ $0.4 \pm 0.3 \mathrm{~mm}, 0.4 \pm 0.3 \mathrm{~mm}$ であった(Fig. 2 に示した 全データの平均標準偏差)。なお，本研究で測定した 最小照射野 $\left(\mathrm{A}_{\min }\right)$ は $2 * 2 \mathrm{~cm}^{2}$ であり, TRBD に比較対

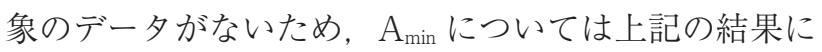
含まれていない.X 線の TRBD と MBDの比較結果 の一例を Fig. 3 に示す。上段に基準照射野である $10 * 10 \mathrm{~cm}^{2}$ の PDDを，下段に測定深 $10 \mathrm{~cm}$ における $6 \mathrm{MV}$ (左) および $10 \mathrm{MV}-\mathrm{FFF}$ (右)のプロファイルを示 す．PDD，プロファイルともに両者は良好に一致した。

電子線の TRBD と MBD の比較結果の一例として, 基準照射野である $10 * 10 \mathrm{~cm}^{2}$ の結果を Fig. 4 に示す. 電子線に扔いて, TRBD と MBD の差(全スキャン デー夕の平均墂準偏差) は PDD が-1.2 $\pm 1.3 \%$ であり, すべての測定条件において PDD の一致が悪く, $R_{50}$ で 最大 $1.6 \mathrm{~mm}$ の相違がみられた $\left(20 \mathrm{MeV}, 25 * 25 \mathrm{~cm}^{2}\right)$.

\section{2-2 治療計画装置の計算線量と実測線量の比較}

計算線量と実測線量の比較結果を Fig. 5 および Table 4 に示す。均質媒質に扔けるすべての検証条件 の計算線量と実測線量の差 (平均墂準偏差) は, AAA， AXBのそれぞれに対して $0.1 \pm 0.3 \%$ （最大 $1.2 \%), 0.0 \pm 0.3 \%$ (最大 $1.0 \%$ )であり, 同一測定条件で の OPF の検証結果については, 同様に $0.1 \pm 0.2 \%$ (最大 $0.4 \%$ )， $-0.1 \pm 0.2 \%$ (最大 $0.5 \%$ )であった (Fig. 5 上段). また，不均質媒質におけるすべての検証条件の計算線 量と実測線量の差(平均土標準偏差)は, $\mathrm{AAA}, \mathrm{AXB}$ のそれぞれに対して $0.7 \pm 1.4 \%$ (最大 $6.3 \%$ )， $0.6 \pm 1.1 \%$ (最大 $4.8 \%$ )であった(Fig. 5 下段)。計算線量と実測 線量は 95\%信頼区間内に打いて, 均質媒質条件では $\pm 1 \%$ ，不均質媒質条件では $\pm 3 \%$ で一致した。 

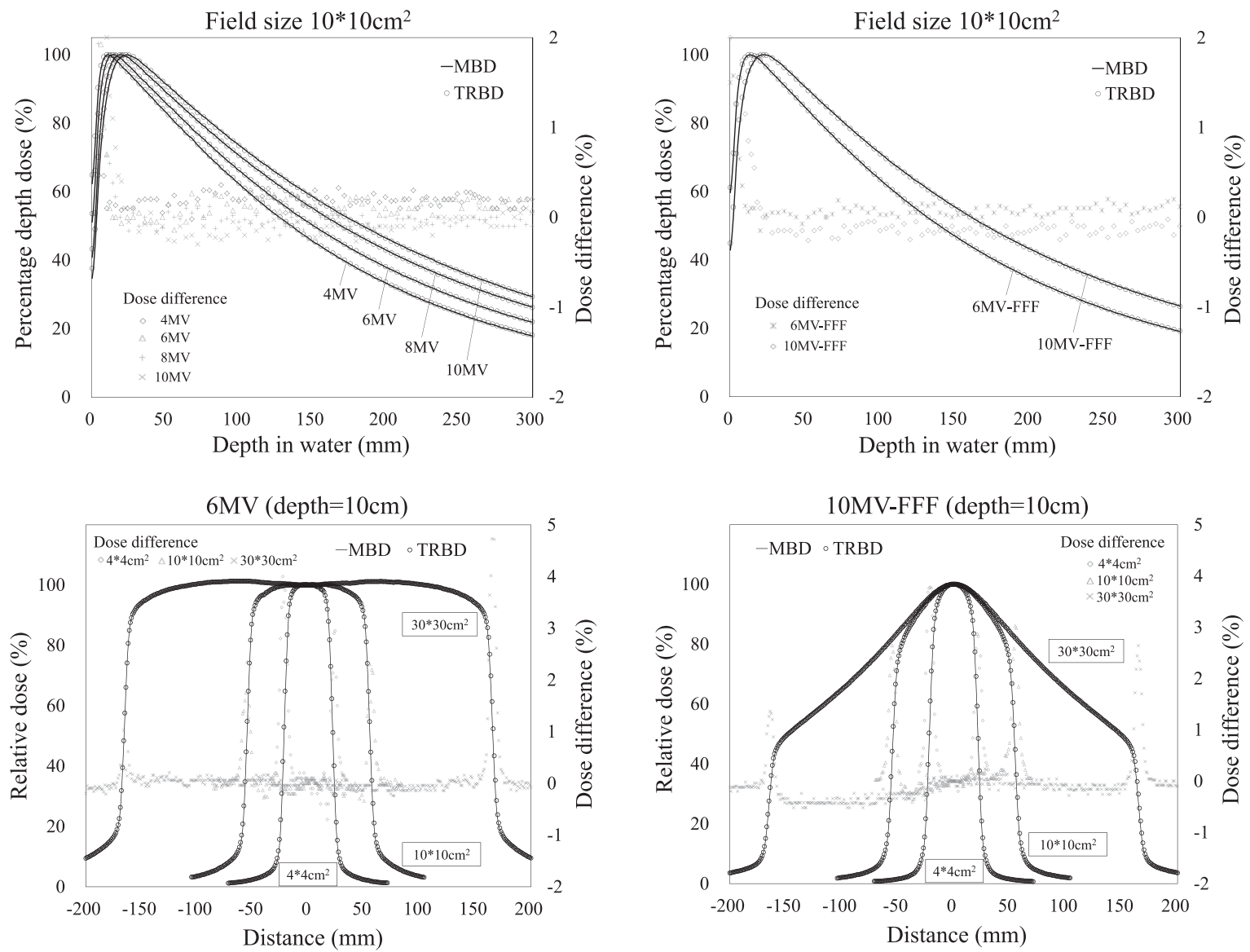

Fig. 3 Comparison of PDDs (upper panels) and profiles (lower panels) of TRBD (circles) and MBD (solid line) for the flattening filtered beam (left panels) and flattening filtered free beam (right panels).

The secondary vertical axis shows dose differences between the two data series.

The mean difference in PDDs was $0.0 \%$ (DD), $0.4 \mathrm{~mm}$ (DTA) and the mean difference in profiles was $-0.1 \%$ (DD), $0.4 \mathrm{~mm}$ (DTA).

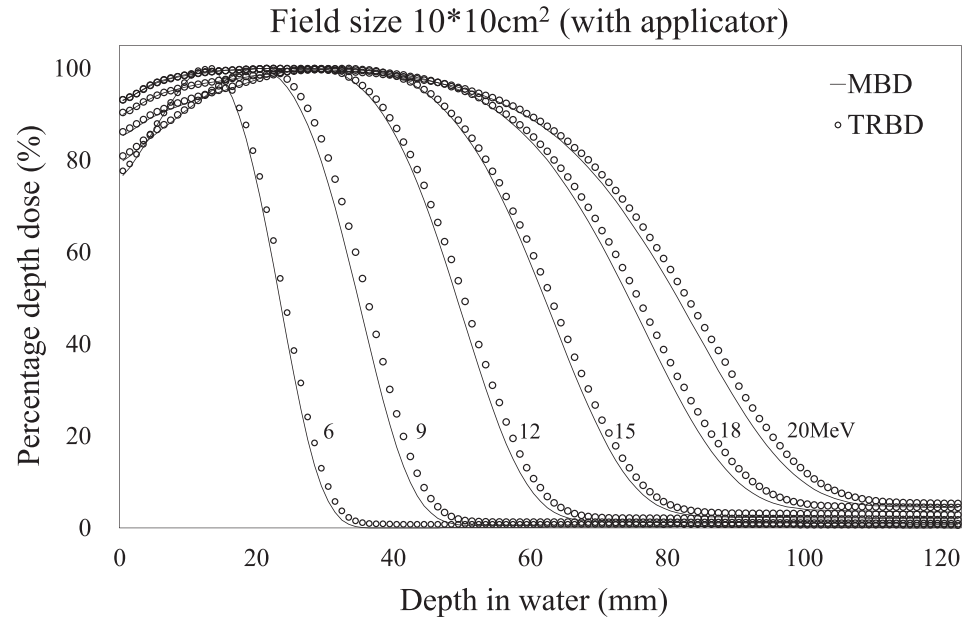

Fig. 4 Comparison of PDDs of TRBD (circles) and MBD (solid line) for the 6-20 MeV electron beams.

The secondary vertical axis shows dose differences between the two data series. 
Homogeneous condition
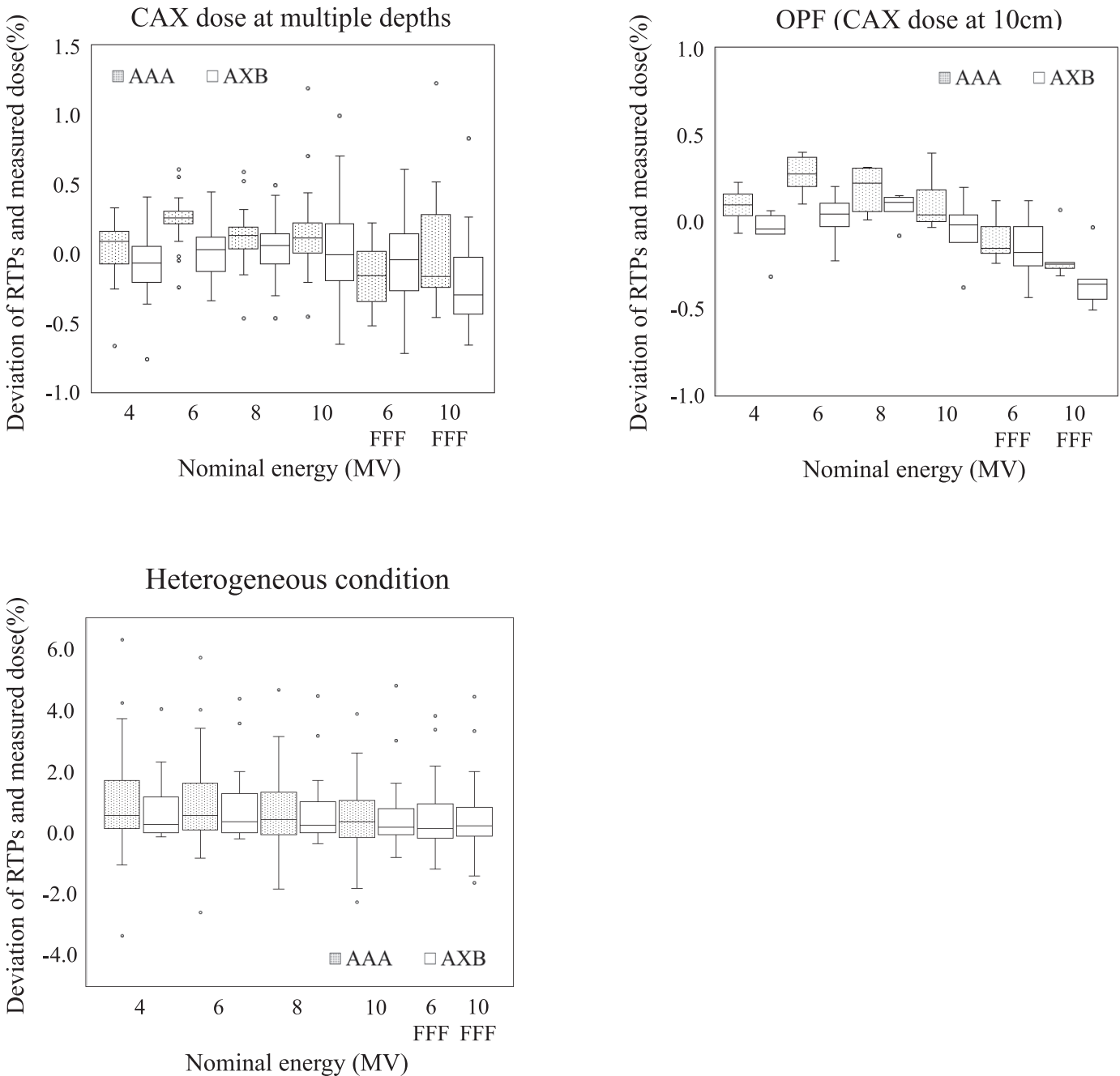

Fig. 5 Box plots of differences between measured and calculated dose by AAA and AcurosXB algorithms in the homogeneity (upper panel) and heterogeneity conditions (lower panel).

The central mark on the box is the median, while the bottom and top edges indicate the 25 th and 75 th percentiles, respectively.

\section{2-3 コミッショニングに要した期間}

受入試験終了から臨床使用開始まで 43 日 (1.4 カ月) を要した。そのうち TRBD の検証に要した期間は 6 日であった(Fig. 6).

\section{3. 考 察}

われわれはビームデー夕測定の代わりに抜き取り検 証を行うことで，精度を落とすことなくコミッショニ ング期間の短縮を図った。この抜き取り検証でビーム デー夕を比較する際には，まず初めに治療エネルギー とプロファイルの一致を確認する必要があるため,こ れらの変化に敏感な照射野サイズの選択が重要とな る。そこでわれわれは治療エネルギーの変化が PDD およびプロファイルに与える影響について，モンテカ ルロシミュレーションにて事前に評価を行った。モン テカルロシミュレーションコードには $\mathrm{EGSnrc}^{17)}$ の
ユーザーコード BEAMnrc ${ }^{18)}$ と DOSXYZnrc ${ }^{19)}$ を使用 した. BEAMnrcコード内にVarian 社より提供され た情報をもとに加速器構造を詳細に再現した。 $10 \mathrm{MV}$ $\mathrm{X}$ 線に対して実際の装置で測定した線量分布に一致 するように加速電子のパラメータを調整した，平均工 ネルギーが $10.5 \mathrm{MeV}$ (ガウス分布 FWHM 3\%)におい て最も一致する結果を得られた。これに対して平均工 ネルギーを $\pm 1 \mathrm{MeV}$ 変化させたときの線量分布を求め た. FFFビームは, この調整したビームに対してフ ラットニングフィルタを取り外した状態でシミュレー ションを行い, 同様に平均エネルギーを $\pm 1 \mathrm{MeV}$ 変化 させて線量分布を計算した. Figure 7 にモンテカル ロシミュレーションの結果を示す。上段にFF ビーム の PDDを，下段にFFビームのプロファイルのシ ミュレーション結果を示しており，照射野サイズの違 いによる，深部線量の変化扮よび軸外プロファイルの 
Table 4 Difference between calculated dose and measured dose in AAA and AcurosXB

\begin{tabular}{|c|c|c|c|c|c|c|c|c|}
\hline \multirow{3}{*}{ Plan type } & \multirow{3}{*}{ Evaluated } & \multirow{3}{*}{ Energy } & \multicolumn{6}{|c|}{ Dose deviation $(\%)$} \\
\hline & & & \multicolumn{3}{|c|}{ AAA } & \multicolumn{3}{|c|}{ AcurosXB } \\
\hline & & & Mean & $\mathrm{SD}$ & $|\operatorname{Max}|$ & Mean & $\mathrm{SD}$ & $|\mathrm{Max}|$ \\
\hline \multirow{10}{*}{$\begin{array}{l}\text { Simple geometry } \\
\text { (Homogeneous) }\end{array}$} & \multirow{5}{*}{$\begin{array}{l}\text { CAX dose at multiple depths } \\
(\mathrm{d}=2.4,5,20 \mathrm{~cm})\end{array}$} & $4 \mathrm{MV}$ & 0.02 & 0.18 & 0.67 & -0.10 & 0.23 & 0.77 \\
\hline & & $6 \mathrm{MV}$ & 0.24 & 0.15 & 0.60 & 0.02 & 0.19 & 0.44 \\
\hline & & $8 \mathrm{MV}$ & 0.09 & 0.18 & 0.59 & 0.03 & 0.23 & 0.49 \\
\hline & & $6 \mathrm{MV}-\mathrm{FFF}$ & -0.18 & 0.23 & 0.52 & -0.03 & 0.31 & 0.72 \\
\hline & & $10 \mathrm{MV}-\mathrm{FFF}$ & 0.05 & 0.40 & 1.23 & -0.16 & 0.33 & 0.83 \\
\hline & \multirow[t]{5}{*}{ OPF (CAX dose at $10 \mathrm{~cm})$} & $4 \mathrm{MV}$ & 0.10 & 0.09 & 0.23 & -0.06 & 0.12 & 0.32 \\
\hline & & $6 \mathrm{MV}$ & 0.27 & 0.09 & 0.40 & 0.03 & 0.13 & 0.23 \\
\hline & & $8 \mathrm{MV}$ & 0.19 & 0.11 & 0.31 & 0.09 & 0.07 & 0.15 \\
\hline & & $10 \mathrm{MV}$ & 0.10 & 0.14 & 0.40 & -0.05 & 0.16 & 0.38 \\
\hline & & $10 \mathrm{MV}-\mathrm{FFF}$ & -0.21 & 0.12 & 0.31 & -0.34 & 0.14 & 0.51 \\
\hline \multirow{6}{*}{$\begin{array}{l}\text { Clinical } \\
\text { (Heterogeneous) }\end{array}$} & \multirow[t]{6}{*}{ Point dose at multiple locations } & $4 \mathrm{MV}$ & 1.00 & 1.64 & 6.31 & 0.76 & 1.14 & 4.04 \\
\hline & & $6 \mathrm{MV}$ & 0.93 & 1.51 & 5.73 & 0.77 & 1.13 & 4.37 \\
\hline & & $8 \mathrm{MV}$ & 0.59 & 1.33 & 4.67 & 0.66 & 1.09 & 4.47 \\
\hline & & $10 \mathrm{MV}$ & 0.43 & 1.21 & 3.89 & 0.56 & 1.15 & 4.80 \\
\hline & & $6 \mathrm{MV}-\mathrm{FFF}$ & & & & 0.50 & 1.08 & 3.82 \\
\hline & & $10 \mathrm{MV}-\mathrm{FFF}$ & & & & 0.49 & 1.20 & 4.45 \\
\hline
\end{tabular}

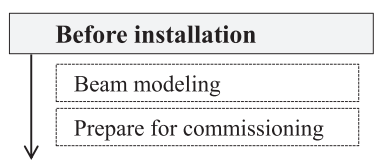

\section{After installation}

\begin{tabular}{|c|}
\hline Acceptance test \\
\hline $\begin{array}{l}\text { 1-4. Beam data } \\
\text { verification }\end{array}$ \\
\hline $\begin{array}{l}\text { 1-5. Calculated dose } \\
\text { verification }\end{array}$ \\
\hline $\begin{array}{l}\text { 1-6. Additional } \\
\text { verification }\end{array}$ \\
\hline Clinical use \\
\hline
\end{tabular}

\section{[ Period ] [ Elapsed time ]}

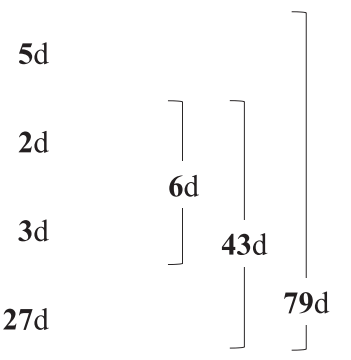

Fig. 6 Our commissioning workflow and number of days required to commission the Linac and treatment planning system.

変化を示している。この結果よりPDDは照射野サイ ズが小さいほど加速電子エネルギーの変化に対する深 部の線量差が大きくなっている。また, プロファイル は照射野サイズが大きく，また軸外ほど加速電子エネ ルギーの変化に対する線量差が大きくなっている。 つ まり，小さい照射野サイズの PDD，大きい照射野サイ ズのプロファイルはエネルギーの変化に敏感であると 考えられる。この傾向はFFFビームについても同様 であった。以上より本研究では測定照射野サイズ $4 * 4$ $\mathrm{cm}^{2}, \quad 10 * 10 \mathrm{~cm}^{2}, 30 * 30 \mathrm{~cm}^{2}$ を選択した. Lim らは照 射野サイズ $3 * 3 \mathrm{~cm}^{2}, 10 * 10 \mathrm{~cm}^{2}, 30 * 30 \mathrm{~cm}^{2}$ における
$\mathrm{MBD}$ と $\mathrm{TRBD}$ の差について, $\mathrm{PDD}$ は平均 $0.5 \%$, プ ロファイル (平坦度)は $0.4 \%(\mathrm{FF}), 1.0 \%(\mathrm{FFF})$ であっ たと報告している ${ }^{9)}$. 本研究において, X 線では $\mathrm{TRBD}$ と $\mathrm{MBD}$ の差は PDD, プロファイルともに $1 \%$ 未満であり，先行研究の報告と同様の結果となった。 加えて, 線量分布の位置差も PDD およびプロファイ ルのどちらも平均が $0.5 \mathrm{~mm}$ 未満であったことから,

TRBD は本リニアックの特性を十分反映できると判 断した。

電子線に関してはすべての測定条件において PDD の一致が悪く， $\mathrm{R}_{50}$ で最大 $1.6 \mathrm{~mm}$ の相違がみられた $\left(20 \mathrm{MeV}, 25 * 25 \mathrm{~cm}^{2}\right)$. Hurst らは電子線 $\mathrm{R}_{50}$ におけ る 4 装置間の最大偏差は $1.5 \mathrm{~mm}$ であったと報告して おり ${ }^{7)}$, 本報告の結果と一致している。差が生じた原 因としては，ベンダがビーム調整を実施した際との測 定条件の違いが考えられる. 今回の導入時には水を封 入したアクリル製ファントム (Fig. 8)を使用し, 許容 值は $\mathrm{R}_{50} \pm 1 \mathrm{~mm}$ にてエネルギーの調整および受入試験 を行い, 仕様内であることを確認したが, 三次元水 ファントムとの散乱条件や壁材の有無等の違いによ り，線質の差が生じたものと推察される。たとえ受入 試験の仕様内であったとしても，電子線のエネルギー は測定条件の差に大きく影響を受けるため, 施設間の 測定結果に差が生じやすく, TRBD とは必ずしも一致 しないことに注意が必要である。よって，X 線と同様 にTRBD を用いて電子線のビームモデリングを行う 際は, 受入試験時もしくはその直後に三次元水ファン 

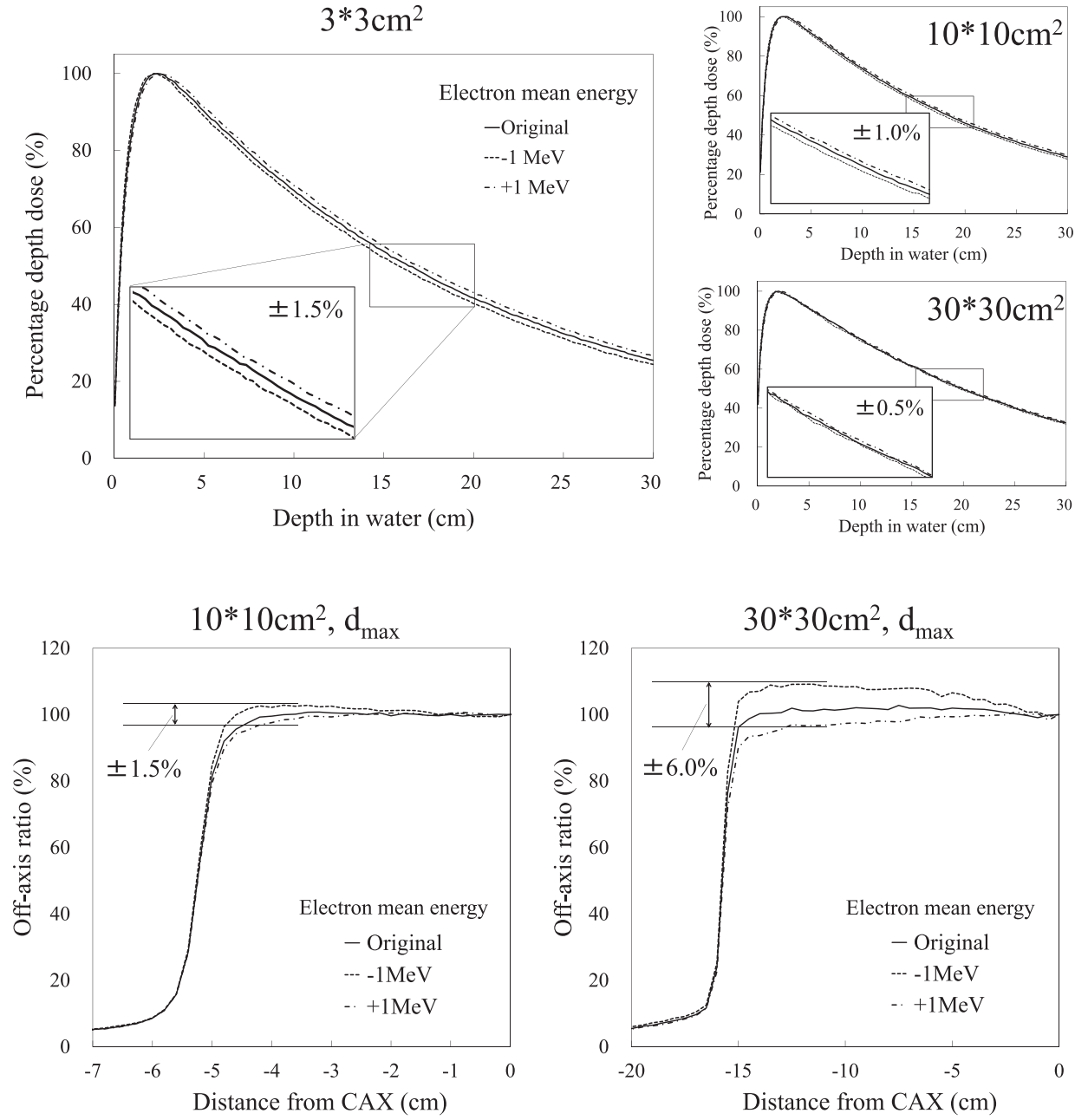

Fig. 7 A energy sensitivity study on PDDs (upper panel) and profiles (lower panel) at $10 \mathrm{MV}$ photon beam with/without flattening filter. The energy of the incident electron beam is varied from 9.5 to $11.5 \mathrm{MeV}$ in steps of $1.0 \mathrm{MeV}$, with an energy spread of 3\% FWHM.

トムを用いたビーム確認および調整の必要性につい て，ベンダとともに十分検討すべきと考える．以上よ り，本研究において電子線の TRBD はビームモデリ ングに十分な精度がないと判断し，電子線線量計算ア ルゴリズム (electron Monte Carlo: eMC)のモデリング は実施しなかった。電子線治療計画における TRBD の活用法については今後の検討課題と捉えている.

$\mathrm{X}$ 線に扔ける治療計画装置の計算線量と実測線量 の比較結果について, 均質媒質条件では線量差の平均 が $0.0 \%$ (最大 $1.2 \%$ )であり, また OPF についても平 均が $0.0 \%$ (最大 $0.5 \%$ ) と良好な一致を確認できた。し かし, 本研究では標準計測法 12 とは異なる測定法で 取得された OPFを用いてビームモデリングを行った ため, 本手法の妥当性について考察する。 OPF は照 射野サイズ以外では光子エネルギーに依存しており， $\mathrm{PDD}$ や $\mathrm{TPR}_{20.10}$ でエネルギーが一致していれば，理 論上測定基準深によって OPF に大きな差は生じない ものと考えられる。また, Beyerらは, TrueBeam は
従来のリニアックと比較してヘッド構造が異なり, OPF の照射野依存性が小さいこと，また装置間のば らつきが小さいことを報告している $(<0.5 \%)^{8)}$ 。これ らの報告に加え, 本研究における検証結果が良好だっ たことから, OPF の測定基準深の差が計算線量に与 える影響は小さいと考えられる。よって，われわれは 本装置における $\mathrm{OPF}$ の確認は, 本研究で行った方法 (基準深 $5 \mathrm{~cm}$ のデータで計算された $10 \mathrm{~cm}$ 深の線量 を検証する方法)で十分であると判断した．また，不 均質媒質で検証を行った臨床条件のうち一部の照射条 件 (Case2, AAA) で許容值外となった(最大誤差 6.3\%)。同一ジオメトリのAXBの計算結果と比較す ると約 5\%の差があることから，この誤差はビーム データの差によるものではなく, 線量計算アルゴリズ ムの計算精度をみているものと考元られる ${ }^{20)}$. 具体的 には AAAの不均質領域におけるカーネル補正の不確 かさが主な原因と考えられ ${ }^{21)}$ ，これらの条件を除くほ とんどの条件に打いて十分な計算精度を確認できた。 


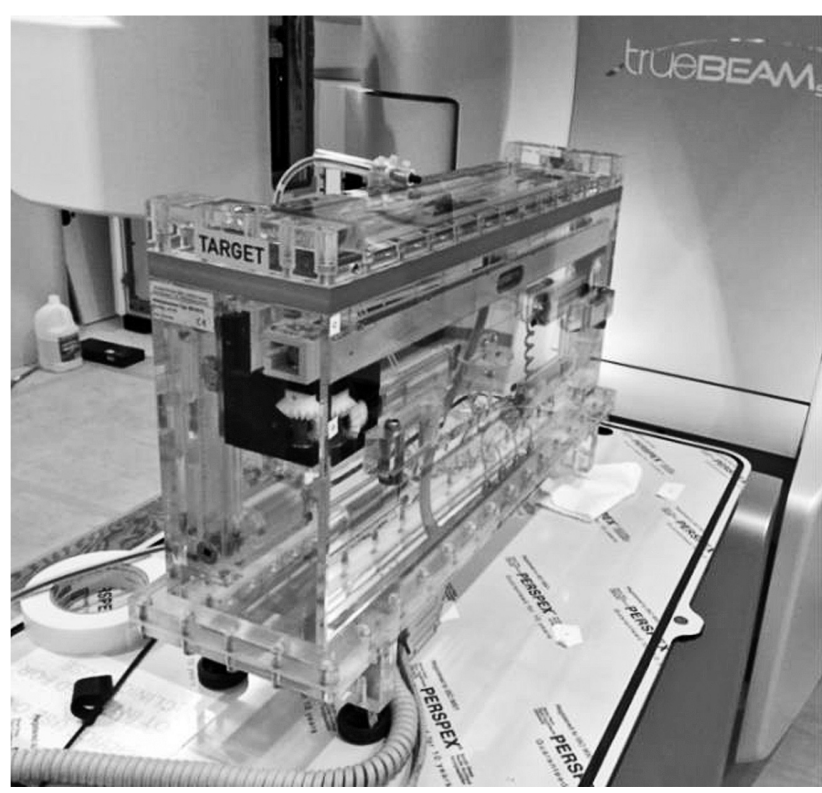

Fig. 8 Water phantom used for acceptance test and beam adjustment (Waterphantom Typ. BS2010, Scanditronix Wellhofer).

また，定位放射線治療のコミッショニングの際，小照 射野 (1.0-2.0 cm) の線量検証に扮いて, 約 3-5\%の系 統誤差が生じた。これは TRBD の最小照射野が $3 * 3$ $\mathrm{cm}^{2}$ であり，それより小さい照射野については外挿值 で計算されていること，またTRBD が小照射野にお いても同一の電離箱 (CC13) で測定されたデータであ ることが影響していると考えた。そこでわれわれは $3 * 3 \mathrm{~cm}^{2}$ 未満の OPF のみ測定デー夕を追加登録し, 結果として線量誤差は改善した。照射野の OPFに ついては, 側方電子平衡の不成立や検出器の部分体積 効果等により, 使用する検出器によって結果が大きく 異なることが知られているため ${ }^{22,23)}$, 上記の追加デー 夕は小型検出器 (半導体検出器㧍よび体積 $0.01 \mathrm{~cm}^{3}$ の 小型電離箱)の測定值より決定した。 以上ょり, TRBD に含まれていないデー夕については，施設で実 施予定の治療のコミッショニング時に必要なデー夕を 追加していくことが必要と考えられる.

今回われわれはビームモデリングに必要な $\mathrm{MBD}$ を すべて取得していないため, MBDのビームモデルと の直接比較ができていない. Breitman らはMBD で モデリングした AAA の計算精度について，不均質 ファントム内に抒いて $2.1 \%$ (最大 $5.3 \%$ )であったと報 告している ${ }^{24)}$. 本研究において, TRBD でモデリング された $\mathrm{AAA} の$ 計算精度は, 単純条件で最大 $1.2 \%$, 臨 床条件で最大 $6.3 \%$ であることから，ソフトウェアの バージョンの違いはあるものの，MBD を使用した場 合と同等の精度でモデリングできていると考えられる.
本研究では導入計画時より TRBD を用いたビーム モデリングを想定していたため、リニアック搬入前に Eclipse 内の光子線線量計算アルゴリズムのモデリン グを行った。これによりコミッショニング期間が短縮 することはもちろん, 入念なスケジュールの考案や検 証用治療計画の作成に対して十分な時間をかけること ができ，効率的な導入作業が実現した，また，TRBD を用いたモデリング作業はファイルをインポートする だけの単純作業であり，誤った測定データを入力する 危険性が少なくなるため, 安全性の向上も期待できる.

TRBD を用いることで短縮した時間をVMAT の MLC パラメータ調整等, 他のコミッショニング項目 に充当することで, 結果としてガイドラインが推奨す る半分以下の期間で臨床使用開始することができた. ただ，必ずしも期間を短縮できるわけではない，仮に TRBD と MBD の間に許容できない乘離が認められ た場合や，線量検証で大きな誤差が認められた場合に は, 装置のビーム調整もしくは実測べースのモデリン グへの切り替えが必要となるため, 本研究で示したよ うな期間短縮は望めない。期間短縮はあくまで可能性 と捉え, 従来どおり精度と安全性を第一に考えた立ち 上げ計画の立案が肝要となる。また，本研究は装置一 台のみの検証であり，すべての装置で同様の結果にな るとは限らないため注意が必要である。全く検証を行 わずに TRBD を使用することは避けるべきであり， リニアックの調整・設定ミスを検出する意味でも, 自 施設の測定データとの比較検証は必須と考える. 以上 より,リニアックの精度を過信せず，TRBD の特性を よく理解したうえで使用することで, 効率的で安全な リニアックの立ち上げを実現できるといえる.

\section{4. 結 語}

本研究において, TrueBeam STx の MBD と GBD は $1 \%$ 以内で一致し，GBD でモデリングした線量計 算アルゴリズムの計算精度は均質条件で $1 \%$, 不均質 条件で $\pm 3 \%$ 以内となった。また, VMATを含めた臨 床使用開始までに要した期間は受入試験終了後より 1.4 カ月であった。 以上より, 治療計画装置のコミッ ショニングに㧍いて，GBD を使用することで線量計 算精度を落とすことなく準備期間を短縮することがで き, 高精度治療の早期提供が可能となることが明らか となった。

なお, 本研究の要旨は第 74 回日本放射線技術学会 総会学術大会(2018 年, 横浜)にて発表した. 
1）放射線治療品質管理機構．放射線治療装置導入に関する コミッショニング必要期間について. https://www.qcrt. org/document/comisshoning proposal.pdf (Accessed 2018.5.11).

2) Smilowitz JB, Das IJ, Feygelman V, et al. AAPM medical physics practice guideline 5.a.: Commissioning and QA of treatment planning dose calculations -megavoltage photon and electron beams. J Appl Clin Med Phys 2015; 16(5): 14-34.

3) WHO. Radiotherapy Risk Profile. 2008. https://www.who.int/ patientsafety/activities/technical/radiotherapy_risk_profile.pdf (Accessed 2018.7.21).

4) Das IJ, Cheng CW, Watts RJ, et al. Accelerator beam data commissioning equipment and procedures: report of the TG106 of the Therapy Physics Committee of the AAPM. Med Phys 2008; 35(9): 4186-4215.

5) Das IJ, Njeh CF, Orton CG. Point/counterpoint: vendor provided machine data should never be used as a substitute for fully commissioning a linear accelerator. Med Phys 2012; 39 (2): $569-572$.

6) Chang $\mathrm{Z}, \mathrm{Wu} \mathrm{Q}$, Adamson $\mathrm{J}$, et al. Commissioning and dosimetric characteristics of TrueBeam system: composite data of three TrueBeam machines. Med Phys 2012; 39(11): 69817018.

7) Glide-Hurst C, Bellon M, Foster R, et al. Commissioning of the Varian TrueBeam linear accelerator: a multi-institutional study. Med Phys 2013; 40(3): 031719.

8) Beyer GP. Commissioning measurements for photon beam data on three TrueBeam linear accelerators, and comparison with Trilogy and Clinac 2100 linear accelerators. J Appl Clin Med Phys 2013; 14(1): 273-288.

9) Lim S, Tang G, LoSasso T, et al. A comparative study of commissioning data of two TrueBeam LINACs with TrueBeam representative beam data. Med Phys 2013; 40(6): 210-210.

10) Varian Medical Systems. TrueBeam Representative Beam Data for Eclipse. 2015.

11）日本医学物理学会編. 外部放射線治療における吸収線量 の標準計測法(標準計測法 12). 東京：通商産業研究社, 2012.

12) IAEA. Technical Reports Series No.430; Commissioning and Quality Assurance of Computerized Planning Systems for Radiation Treatment of Cancer. International Atomic Energy
Agency, Austria, 2004.

13) IAEA. TECDOC No. 1583; Commissioning of Radiotherapy Treatment Planning Systems: Testing for Typical External Beam Treatment Techniques. International Atomic Energy Agency, Austria, 2008.

14) Fraass B, Doppke K, Hunt M, et al. American Association of Physicists in Medicine Radiation Therapy Committee Task Group 53: quality assurance for clinical radiotherapy treatment planning. Med Phys 1998; 25(10): 1773-1829.

15) Ezzell GA, Burmeister JW, Dogan N, et al. IMRT commissioning: multiple institution planning and dosimetry comparisons, a report from AAPM Task Group 119. Med Phys 2009; 36(11): 5359-5373.

16) Mijnheer B, Olszewska A, Fiorino C, et al. Quality assurance of treatment planning systems, practical examples for non-IMRT photon beams. ESTRO Booklet No.7, ESTRO, Belgium, 2004.

17) Kawrakow I, Mainegra-Hing E, Rogers DW, et al. The EGSnrc Code System: Monte Carlo simulation of electron and photon transport. Technical Report PIRS-701, National Research Council Canada, 2006

18) Rogers DW, Faddegon BA, Ding GX, et al. BEAM: a Monte Carlo code to simulate radiotherapy treatment units. Med Phys 1995; 22(5): 503-524.

19) Walters BRB, Kawrakow I, Rogers DWO. DOSXYZnrc Users Manual. NRC Report PIRS-794. National Research Council of Canada. 2003.

20) Bush K, Gagne IM, Zavgorodni S, et al. Dosimetric validation of Acuros XB with Monte Carlo methods for photon dose calculations. Med Phys 2011; 38(4): 2208-2221.

21）中口裕二, 荒木不次男, 丸山雅人，他．放射線治療計画装 置に扮ける不均質領域の線量計算精度の評価一Monte Carlo 計算との比較一。 日放技学誌 2010; 66(4): 322-333.

22) Alfonso R, Andreo P, Capote R, et al. A new formalism for reference dosimetry of small and nonstandard fields. Med Phys 2008; 35(11): 5179-5186.

23) IAEA. Technical Reports Series No.483; Dosimetry of Small Static Fields Used in External Beam Radiotherapy. International Atomic Energy Agency, Austria, 2017.

24) Breitman $K$, Rathee $S$, Newcomb $C$, et al. Experimental validation of the Eclipse AAA algorithm. J Appl Clin Med Phys 2007; 8(2): 76-92. 